\title{
Teen Mother and Child Experiences in a Parent-Child Music Program
}

\author{
Jean Emmerson, Jennifer J. Nicol, Laureen J. McIntyre \\ Department of Educational Psychology \& Special Education, University of Saskatchewan, Saskatoon, Canada \\ Email: jennifer.nicol@usask.ca
}

Received 18 March 2016; accepted 16 May 2016; published 19 May 2016

Copyright (C) 2016 by authors and Scientific Research Publishing Inc.

This work is licensed under the Creative Commons Attribution International License (CC BY).

http://creativecommons.org/licenses/by/4.0/

(c) (;) Open Access

\begin{abstract}
In this paper, we outline the rationale and growing research base for parent-child music programs as a means to strengthen caregiver-child bonding, with particular interest in positively impacting the lives of adolescent mothers and their infants. Secondary schools that offer daycare and parenting classes are ideal sites for delivering parent-child music programs, and music educators are well situated to become involved in such initiatives. To illustrate, the findings of a pilot program implemented in a mid-size Canadian Prairie city are presented. Working with a local parent-child music instructor, Cree Elder and Métis singer-songwriter, an 8-week culturally responsive music program based on Kindermusik (2010) was designed and delivered to 13 young women and their infants. Data were collected using participant-observations; focus group interviews with the mothers and individual interviews with the parent-child music instructor, an Elder, and school staff; informal check-in interviews with most adolescent mothers; and video footage and photographs taken during the parent-child music program. The Listening Guide (Gilligan, Spencer, Weinberg, \& Bertsch, 2003) was used to analyze focus group interviews and thematic analysis (Braun \& Clarke, 2006) was utilized to elucidate the other data. Findings suggest that practical music-based interactions, which model and reinforce parenting skills through welcoming, informal, positive and culturally responsive activities, strengthened mother-infant connections, enhanced maternal wellbeing, and developed children's social skills.
\end{abstract}

\section{Keywords}

Adolescent Motherhood, Parent-Child Music Programs, Attachment, Culturally Responsive, Schools

\section{Introduction}

Young mothers and their children are an identified socially vulnerable population. Canadian adolescent mothers are less likely than adult mothers to complete high school (Human Resources and Skills Development Canada, 
2011), and mothers with less education have fewer economic opportunities (Eshbaugh, Lempers, \& Luze, 2006) and a greater likelihood of long-term low income (Luong, 2008). Correspondingly, young mothers with less education report feeling like they have fewer opportunities and experience depression (Eshbaugh, Lempers, \& Luze, 2006). Furthermore, young mothers and pregnant youth face stigma, which can lead to social isolation (MacDonald et al., 2011; Olsen, 2005).

As parents, adolescent mothers and their children have been identified as more vulnerable to developing less secure attachment patterns than older mothers and their children (Emery, Paquette, \& Bigras, 2008; Van Ijzendoorn, Schuengel, \& Bakermans-Kranenburg, 1999). Although adolescent mothers with more education, less parenting stress, and higher social support satisfaction are more likely to have secure attachment patterns with their children (Emery, Pacquette, \& Bigras, 2008), evidence suggests that in general, young mothers tend to be less responsive to their infants than older mothers, have fewer positive interactions, and vocalize less with their infants (Borkowski, Farris, Whitman, Carothers, Weed, \& Keogh, 2007; Culp, Appelbaum, Osofsky, \& Levy, 1988; Tarabulsy, Moran, Pederson, Provost, \& Larose, 2011). This is concerning given that secure parent-child attachment is recognized as a predictor of future health and wellbeing. Bowlby (1969) introduced Attachment Theory in 1969 to underscore the importance of children's relationship with a caring, reliable, and sustained parental figure. Subsequent research suggested that children who are securely attached in their early years: to better recognize, judge and understand emotions, have more competent social problem-solving skills; and are less lonely than those children who are insecurely attached (Raikes \& Thompson, 2008; Steele, Steele, \& Croft, 2008; Thompson, 2008). Sensitive, consistent, timely, and appropriate parental responses to infant cues create secure attachment whereas insecure attachment results from a dearth of these responses (Cozolino, 2010; Creighton, 2011; Siegel, 1999; Steele, Steele, \& Croft, 2008).

Fortunately however, attachment is malleable, and a growing small body of literature suggests that music provides a promising means to positively influence attachment patterns. Secure attachment is related to responsive attunement with an infant's emotional state and with caregivers sharing positive emotions with their infants and soothing distressing emotions (Schore, 2001; Siegel, 1999). When caregivers attune to an infant's emotions (e.g., by calming a crying infant) they entrain the infant's autonomic system to function within optimal levels and thus co-regulate the emotions (Newton, 2008). In this way, infants learn to modulate, control, and selfregulate their emotions (Cozolino, 2010; Schore, 2001; Weinfield, Sroufe, Egeland, \& Carlson, 2008). Emotional self-regulation promotes security, autonomy, and resilience in young children (Rolfe, 2004); leads to feelings of happiness; and provides the foundation for school readiness (Newton, 2008). The interactions that help infants with emotional self-regulation also develop attachment and shape neural connections and brain structure, influencing future development (Cozolino, 2010; Gardner \& Goldson, 2002; Schore, 2001; Siegel, 1999).

According to a meta-analysis of 75 studies conducted on caregiver-infant attachment with more than 4,500 caregiver-child dyads, behavior-based, reciprocal, and mutually reinforcing interactions that promoted caregiver sensitivity and responsiveness were most likely to change caregiver behavior and influence attachment patterns (Dunst \& Kassow, 2008). As recognized by music educators, music therapists, ethnomusicologists, and music psychologists, musical interactions are behavior-based, reciprocal, and mutually reinforcing.

\subsection{Music and Singing: Strengthening Mother-Infant Bonds}

Musical interaction with infants occurs across all cultures and around the world. Infants and young children are uniquely equipped to process, appreciate, and participate in music activities (Papousek, 1996), they have musical preferences (Trainor, 1996), and are motivated to imitate and play vocally (Papousek, 1996). Parents and babies imitate each other's musical voice sounds when communicating, which is believed to develop empathy (Malloch, 1999). Singing to infants is a common musical activity for parents (Ilari, 2005), which modulates infant states of arousal and attention (Papousek, 1996) such as when entertaining and arousing a happy baby or soothing and lulling a sleepy baby. Testing cortisol levels in infants confirms that playful songs arouse babies while lullabies quiet them (Shenfield, Trehub, \& Nakata, 2003). Others have established connections between parent-infant attachment, infant self-regulation, and infant-directed vocalizations and singing (Creighton, 2011; Dissanayake, 2000; Longhi, 2009; Mackenzie \& Hamlett, 2005; Nakata \& Trehub, 2004; O'Gorman, 2007; Papousek, 1996; Trainor, 1996). Singing also passes on ethnic and cultural traditions (Custodero, 2006; Ilari, 2005).

Synchronized movement is another characteristic of musical interactions. Many rhythmic activities (e.g., walking, talking, clapping hands, rocking a baby) become synchronized when performed in a group because 
body rhythms entrain to musical rhythms (Schneck, Berger, \& Rowland, 2006). Children's songs are accompanied by rhythmic movements such as swaying (Trainor, 1996), which may facilitate motion-generated synchronization of mother and child, stimulating attunement and bonding (Creighton, 2011). For example, rocking a baby while singing a lullaby can be calming, and moving while singing a lively song can be energizing - for both the mother and infant. Based on a review of the literature on mother-infant musical interaction and emotional communication, Creighton (2011) concluded that, "The reciprocity of [musical] interactions develops mother-infant attachment which is linked with neurological, emotional and social developmental outcomes for young children" (p. 50). Music helps create social bonds and there is a biological basis for these bonds.

\subsection{Parent-Child Music Groups}

There is a growing literature that explores the musical and extra-musical benefits of music-based programs for parents and their children, programs that build on natural strengths and interests of infants and young children. Much of the literature focuses on mothers, particularly adult mothers. Cumulatively, research findings suggest that parent-child music programs can: 1) encourage engagement and bonding (Edwards, 2011; Lyons, 2000; Nicholson, Berthelsen, Abad, Williams, \& Bradley, 2008; Oldfield, Adams, \& Bunce, 2003; Oldfield \& Bunce, 2001); 2) model parenting skills through children's music and movement activities (Burrell, 2011; Creighton, 2011; Kelly, 2011); 3) nurture parent-child interactions (Edwards, 2011; McDonald et al., 2009); 4) stimulate child developmental and social skills (Kelly, 2011; Nicholson, Berthelsen, Abad, Williams, \& Bradley, 2008); and 5) support maternal wellbeing (Gudmundsdottir \& Gudmundsdottir, 2010). Moreover, parent-child music programs have been well received by families from disadvantaged and marginalized circumstances (Cunningham, 2011; Kelly, 2011; Ledger, 2011; Nicholson et al., 2008). Typically, most parenting programs are not well attended by families who are disadvantaged and marginalized (Nicholson et al., 2008); however, parent-child music programs have been found to be better attended, to encourage positive interactions, to develop children's skills, and to promote inter-family relationships with people in these circumstances (Ledger, 2011; Nicholson et al., 2008).

\subsection{Programs to Support Adolescent Mothers}

The most effective approaches to help vulnerable youth include alternative and community based schools, classroom and school environments that meet student needs and have social skills curriculum, and engaged parents in the school (Dryfoos \& Barkin, 2006). Secondary schools that provide parenting classes for mothers and daycare for their children are ideally situated to improve parent-child interactions, foster cognitive growth in children, and reduce maternal stress (Sadler, Swartz, \& Ryan-Krause, 2003). Furthermore, parenting courses that emphasize reciprocal, behavior-based mother-infant interactions are most effective in changing behavior and promoting maternal sensitivity and responsiveness (Dunst \& Kassow, 2008). As previously noted, music-based interactions align well with reciprocal, behavior-based mother-infant communication and there is a growing base of research that identifies parent-child music programs as successfully nurturing parent-child interactions (Edwards, 2011; McDonald et al., 2009), stimulating child developmental skills (Kelly, 2011), and supporting maternal wellbeing (Gudmundsdottir \& Gudmundsdottir, 2010). However, there is limited literature specific to adolescent mothers. Exceptions included a 10-week music therapy course offered to adolescent mothers in Dublin Ireland (Cunningham, 2011); a 10-week music therapy program offered to disadvantaged parents that included some young mothers in Australia (Nicholson, Berthelsen, Abad, Williams, \& Bradley, 2008), a 12-week program for Icelandic young mothers (Gudmundsdottir \& Gudmundsdottir, 2010); and an 8-week program for 115 adolescent mothers in 11 Canadian communities was developed by McDonald et al. (2009), which included singing amongst other activities. Informed by these studies, we developed and implemented a pilot parent-child music program in a local alternative school providing daycare and parental support for adolescent parents and their children. The mother-infant dyads' experiences with the program were explored using qualitative case study. Ethics approval was sought and received from the appropriate university and educational boards.

\section{Method}

An 8-session modified Kindermusik parent-music program, a franchised program that promotes family bonding and child development skills in young children (Kindermusik, 2010) was developed and delivered for the pur- 
poses of this study in a mid-size Canadian Prairie city alternative high school. Thirteen young mothers (age 16to 21 years) and their infants (age 5 weeks to 25 months) participated. In keeping with case study research, experiential knowledge, continuous compilation of data, extended researcher observation, and the development of relationship and participant empowerment were key considerations (Stake, 2010). Multiple sources were used to generate data. Participant-observations and focus group interviews with the mothers provided primary sources of data. Participant-observations were made by the first author who participated in all sessions and wrote field notes immediately afterwards. Focus group interviews were conducted at the school with the mothers after the second and third music sessions. Secondary sources included individual interviews with the parent-child music instructor, an Elder, and school staff; informal check-in interviews with most adolescent mothers; and video footage and photographs taken during the parent-child music program. The Listening Guide (Gilligan, Spencer, Weinberg, \& Bertsch, 2003) was used to analyze focus group interviews. Thematic analysis (Braun \& Clarke, 2006) and triangulation were used to understand the program and the participants' experiences.

\section{Findings}

\subsection{The Parent-Child Music Program}

The fourth class began with some gentle music in the background and the children chose colorful rattles from a basket in the middle of the circle. One toddler kept trying to touch a new baby. His mother would take his hand and show him how to stroke the baby's head, saying "Gentle", but she needed to keep an eye on him; he almost toppled over on the infant at one point. We sang the "Hello" song and the mothers helped the infants wave. Next came baby massage. The instructor then brought out scarves for peek-a-boo. Most of the babies remembered how to put a filmy scarf over their head and pull it off, and some of them also put the scarf on their mother's head so there was much laughing and interaction. The infants were also responding to the "Toys Away" song, putting things-or throwing them-into the basket. The instructor noticed that some of the children looked sleepy, so we played the Cree lullaby and the babies took turns in the blanket hammock. They loved it, as evidenced by big smiles. Next was the "Goodbye" song with some waving and chatting. We finished a little early since the children were tired.

These participant observation notes captured a typical session. In all, eight 45-minute classes were held, facilitated by a Kindermusik instructor who was assisted by the first author (Emmerson). This is a typical Kindermusik schedule. More unusual but very helpful was the presence of the instructor's son who participated fully and with his mother, offered a modelling opportunity for the young mothers. The sessions were scheduled during regular school hours, during a block of time usually reserved for parenting classes and related subject matter in order to maximize ease of attendance for participants. In keeping with a usual Kindermusik parent-music program, each class began with quiet background children's music and an interactive activity, such as rolling a jingling cloth ball between participants. Next came the Hello song. The instructor sang hello to each child and led the group in motions chosen by the mothers, such as waving, rocking, and tickling their children. Several activities set to music would follow: baby massage, baby exercise (facilitated by the mothers), and peek-a-boo. As well, each class featured a special event: perhaps moving in mother-child pairs to music, dancing to music, or playing a drum. Storytime followed, and the children selected books their mothers read to them. A Goodbye song signalled that the class was about to end. While this was the general sequence of events in each class, the instructor was attuned to group needs and would sometimes substitute an activity that better fit the group dynamics and energy, or shorten a class if the children were tired. Throughout the sessions, the music instructor exhibited warmth and encouragement, creating a nonjudgmental setting where the mothers and children could try new activities and learn at their own pace. She often demonstrated with her son, modelling motherchild attachment and care. She intentionally created a space for the mothers to support each other.

The program was modified to include cultural responsive elements, that is, incorporating the cultural experiences and perspectives of ethnically diverse students (Gay, 2002). In this case, the participant ethnicities mirrored the locale's diversity where much of the population is Aboriginal or of multi-ethnic origin, primarily British, German, French and Ukrainian ancestry. Pre-program planning included consulting with a school board Elder and a Métis singer-songwriter of Cree songs given the proportionally larger Aboriginal population at the high school. The final sample however included just one Aboriginal mother and five infants with aboriginal paternal ancestry plus 12 mothers and eight infants of diverse ethnicities. Recorded Cree music and an Aboriginal 
drum were used during the program as well as recorded reggae music brought in by one of the mothers.

\subsection{The Group over Time}

As the classes progressed over time, the mothers and children became more engaged with the program and one another. The young mothers and their children were hesitant to participate during the first class. By the third class there was a growing sense of community between the young mothers. Two new mothers joined the group and were learning to interact with their children. The children were also learning how to interact with one another appropriately. Increasingly the mother-child pairs appeared to enjoy being together as evidenced by their smiles, laughter, cuddling, and touching. As the classes continued, the children began communicating with one another, the toddlers started dancing, and infants and children began following instructions. The mothers said they felt closer to one another and often chatted, smiling. They became more mutually supportive. For example, the more experienced mothers spontaneously showed how to best help a tired or overactive child, giving the new mothers options they may not have considered. Several of the teens sat quietly with their children during the first class but soon began to attempt new ways of communicating and interacting such as rocking to music, touching their child, making eye contact, talking, and playing together. Some mothers commented that the class had helped them connect with the group and with their child.

\subsection{Experiences with the Parent-Infant Group}

A collective thematic analysis of the data sources generated evidence coalescing around three themes: strengthened mother-infant connection, enhanced maternal wellbeing, and improved children's social skills. Motherchild bonding in the music program was evidenced by more positive and responsive relationships, especially noticeable for several mothers who were initially unsure of how to interact with their infants. For example, in the first session only the instructor and student researcher sang the hello song with the mothers showing only polite interest. But by the fourth session, field notes revealed the following observations (note that pseudonyms are used to protect identities of the participants):

Kylie cuddling her son and both of them looking very happy; Tasha shyly peeking at her daughter's face when we remarked that she was smiling; Callie joining in on all of the activities now that her infant was awake for (and interested in) the whole class; Janna stroking her son's hair, which was sticking up from his nap; and Allayah kissing and hugging a laughing son. In terms of maternal wellbeing and connection, Tasha was much more talkative today, perhaps because the group was smaller and people have been getting to know each other. It was also nice to see Janna and Allayah enjoying Callie's baby now that he is awake. Callie seems happier since her infant has been participating. Perhaps she enjoys all the attention from the other mothers and children. During the hammock activity Allayah said "I'm gonna try this at home, for sure." Tasha mentioned she was starting to sing in the car to her infant.

Maternal wellbeing was seen in the increasingly congenial and mutually supportive interactions between the young mothers. For example, a video taken during the fifth session captured the following interactions:

The group of mothers and children are seated on the floor and focused in on one infant learning to clap ( $a$ social skill) by imitating others. Chatting and laughter amongst the mothers was evident, indicative of maternal wellbeing. The baby massage activity began; a mother seemed a little embarrassed to have the focus on her, but her child appeared entranced with the massage. In the background was a rendition of Twinkle, Twinkle Little Star (Taylor, 1806) featuring children's voices. Emma was leaning over to say hello to a new baby. She then smiled at Callie, the infant's mother, who smiled back. The connection was evident. A short clip of baby exercise was followed by a shot of Emma's baby crawling away from her. She started to intervene, then Allayah picked the baby up. Emma appeared a little uneasy but sat back and observed what happened next: Allayah said to her son, "Look what Mommy has." Allayah's toddler gave the baby a hug. Again, this is evidence of connection, now between children. Meanwhile Lily, who was looking unhappy because her son was busy trying to get a computer to work instead of engaging with her, began to smile because Tasha's child was crawling up to her. She took the infant into her lap. This connection promoted community building by linking her with another mother and child. We next saw Chelle, a new member of the group, saying "He's so unsure." Her child was in the hammock for the first time and the Cree lullaby 
was playing in the background. The music instructor told her that if she thought it best, they would put him back down on the ground. The young mother concurred and the child held her tightly as she picked him up. This indicated secure attachment, as she was the base he returned to when unsure. Next, Lily's son was in the hammock. The instructor's son stood beside her and said "Hi" each time the hammock swayed in his direction. The toddler began to giggle. Lily said, "He just loves it!" Child-to-child and mother-child connection were evident. In the next frame, we began the peeka-boo activity. Translucent scarves had been brought out and the children were delighting in hiding behind sheer purple, green, blue, or yellow fabric. Soon their mothers pulled the scarves off, saying peek-a-boo to mutual smiles. This was evidence of mother-child connection. The instructor explained that the children could learn the names of their body parts through this activity with questions like, "Where's your nose?" The infants began to notice the cameraman, and Emma's child was the first to move towards the camera. When children are securely attached, they are more likely to explore their environment (Newton, 2008). Tasha's infant also saw the camera. She edged in that direction. The next activity involved the young mothers carrying the children while moving around the room and stopping to interact. The video ended with a group shot and a close-up of the Kindermusik blanket that said, "A good beginning never ends".

Developing social skills were observed as the children learned to follow instructions, attempted appropriate touching of other infants (with some help from their mothers), and observed and communicated with one another. For example,

We sang the Hello song and the mothers helped the infants wave. We did some motions to the music and everyone joined in, tickling their babies and rocking. Next, we did baby massage and everyone seemed to enjoy this. The instructor then brought out the scarves for peek-a-boo. Most of the babies remembered how to put the scarf over their head and pull it off, and some of them also put the scarf on their mother's head so there was much laughing and interaction. Most of the infants were also responding to the Toys Away song, putting things-or throwing them-into the basket. The instructor said that some of the children looked sleepy so we played the Cree lullaby and the babies took turns in the hammock. Each infant was placed in the middle of the blanket hammock and was slowly rocked to the music, the instructor on one end and the mother on the other. The babies loved it, as evidenced by big smiles. Next was the Goodbye song with some waving and chatting.

Table 1 summarizes these findings across five data sources: focus group interviews, participant observation, video footage and photographs, and individual interviews.

Table 1. Research results data summary.

\begin{tabular}{|c|c|c|c|}
\hline & Mother-child connection & Maternal wellbeing & Children's social skills \\
\hline Focus group interviews & $\begin{array}{l}\text { Mothers agreed that it was } \\
\text { "Important to spend time with } \\
\text { the kids", the only time to get } \\
\text { together during school }\end{array}$ & $\begin{array}{l}\text { Young mothers said "Glad I } \\
\text { did it since my son loved it" } \\
\text { "Happy I did it" }\end{array}$ & $\begin{array}{l}\text { Child was "More interactive } \\
\text { with more kids," learned to sing } \\
\text { to herself, play peek-a-boo }\end{array}$ \\
\hline $\begin{array}{l}\text { Participant observation } \\
\text { of music classes }\end{array}$ & $\begin{array}{l}\text { Mothers were smiling, cuddling; } \\
\text { learning how to interact with } \\
\text { children; pairs enjoyed being } \\
\text { together (laughing, touching) }\end{array}$ & $\begin{array}{l}\text { Mothers were more congenial, } \\
\text { conversational, mutually } \\
\text { supportive; mothers smiling } \\
\text { at babies, at one another, } \\
\text { holding each others' infants }\end{array}$ & $\begin{array}{l}\text { Children were communicating } \\
\text { with each other; toddlers were } \\
\text { dancing, following instructions } \\
\text { and putting toys away }\end{array}$ \\
\hline $\begin{array}{l}\text { Video footage, } \\
\text { photographs }\end{array}$ & $\begin{array}{l}\text { Mothers and children were } \\
\text { enjoying baby massage, } \\
\text { peek-a-boo, mutual laughter, } \\
\text { cuddling and reading together }\end{array}$ & $\begin{array}{l}\text { Chatting and laughter, mothers } \\
\text { smiling at each other and } \\
\text { connecting with other infants }\end{array}$ & $\begin{array}{l}\text { Child learning to clap, toddler } \\
\text { giving baby a hug, children } \\
\text { observing one another }\end{array}$ \\
\hline \multirow{2}{*}{$\begin{array}{l}\text { Individual interviews } \\
\text { - with mothers } \\
\text { - with music instructor }\end{array}$} & $\begin{array}{l}\text { Classes supported relationships: } \\
\text { "helped me connect with the group } \\
\text { and her" (child) }\end{array}$ & $\begin{array}{l}\text { Connections with the group: } \\
\text { "I guess I'm closer with the } \\
\text { moms," mothers "liked }\end{array}$ & $\begin{array}{l}\text { Mothers said children liked } \\
\text { having fun, playing with toys, } \\
\text { and "the singing" }\end{array}$ \\
\hline & $\begin{array}{l}\text { Mothers enjoyed watching } \\
\text { children have fun and interacting, } \\
\text { comparable to adult mothers }\end{array}$ & $\begin{array}{l}\text { everything" } \\
\text { Community bonding similar to } \\
\text { classes of adult mothers }\end{array}$ & $\begin{array}{l}\text { Social and cognitive skills } \\
\text { appeared similar to those of } \\
\text { children of adult mothers }\end{array}$ \\
\hline
\end{tabular}




\title{
3.4. Instructor Perspective
}

The Kindermusik instructor was experienced in running parent-child music groups so she was well-qualified to comment on how working with adolescent mothers varied from her work with older mothers. She thought the bond that formed between parents as the class went on was similar in younger and older mothers, as was the enjoyment they had at seeing their children having fun and interacting. Although the connections between parents of any age and their children were similar, she noted the young mothers just needed a little more time to learn and develop skills and confidence. She felt that the young mothers had shorter attention spans during activities, less confidence, and less awareness of child development. Furthermore, she observed that if the teens did not enjoy the music or an activity they often would not participate, whereas the adults were more likely to get involved for the benefit of their child regardless of personal preference. Last, she thought that the children's social and cognitive skills were very much like those of children in her usual groups. She said she felt proud of the group of mothers and children, and described them as "wonderful, engaged, caring parents".

\subsection{Participant Perspectives}

Being a young mom, according to the participants, included many joys and challenges but ultimately, having a child made life meaningful. The parent-child music program was a positive experience for them. The I-Poem below presents their voices, a sketch of resiliency as captured in two focus groups: young mothers faced with the challenges of childrearing, succeeding despite difficult relationship with the fathers of their child, and enjoying an opportunity to connect with their child and others through the parent-child music program.

\author{
I didn't want him when he was born \\ I was home by myself \\ I was alone all the time \\ I hated to be alone \\ I had to give up the rest of my teenage life \\ I suffered from postpartum depression \\ I would just start crying sometimes because it was so hard \\ I'm such a mom now-I'd so much rather stay home and be with him \\ I'm doing a pretty good job \\ I feel so good \\ I like not being alone, I'm never alone anywhere now \\ I used to fight with her dad \\ I moved back home. I don't like it too much. I was the one doing everything \\ I got fed up. I just left \\ I sing to him, it just calms him so he gets all snuggly \\ I've been singing lullabies to him since the first day \\ I don't know, we listen to all kinds of music \\ I love music. It calms me down whenever I'm in a pissed-off mood \\ I actually heard about Kindermusik, we were going to enroll \\ I never really looked into it \\ I'm glad I did because then it just gave him more options. I feel like it's a good tool \\ I'm glad that I did it, because my son, he loved it \\ I'm happy I did it \\ I'm happy I went
}

\section{Discussion}

In this study the parent-child music program helped create positive change for teen mothers and their children. Caregiver-child bonding through music was central to the intent of the parent-child music classes, and drew on music's unique characteristics that encourage the forming and sustaining of relationships, e.g., its ability to elicit synchrony, using a strong regular beat to foster more coordinated group singing (Bicknell, 2009; Crowe, 2004). Group synchrony and identification were also assisted with the development of children's social skills and maternal wellbeing. For example, in the video of the fifth class, a six-month-old infant attempted to clap while 
watching an older child clapping, trying to coordinate her movements with those of the other child through group synchrony. In other classes the young mothers synchronized their movements as they rocked their children to the music. This appeared to augment group identification, as seen through smiles and eye contact. Music also made the activities more pleasurable (Crowe, 2004), capitalizing on the children's predisposition to music (Tafuri, 2008), and encouraging social bonds and mother-child connection (Crowe, 2004).

The program's design and implementation aligned with principles of positive psychology and resiliency. The sessions successfully built on positive emotions to promote personal growth and relational intimacy. There was lots of chatting, laughter, cuddling, and smiling; the dyads were engaged, participating actively and purposeful$l y$. According to positive psychology research, positive emotions, engagement, and purpose are the three key criteria for wellbeing (Seligman, 2011). Using encouragement, warmth and care to strengthen mother-child relationships and children's social skills are identified resiliency protective factors (Olsson, Bond, Burns, Vella-Brodrick, \& Sawyer, 2003). Resiliency is also associated with a sense of community and better family relationships (Masten et al., 2009). The participatory nature of the music classes and research allowed the young mothers to watch and learn from one another and compare their experiences of motherhood and music, which helped build community and develop relationships. The focus group interviews expressly gave the young women an opportunity to be heard and to let others know through this research that they were challenging common perceptions of teen motherhood by being caring, capable, and interconnected young women.

\subsection{Limitations}

It is possible that the changes in mother-infant connection, infant social skills, and maternal wellbeing could have happened independent of the parent-music class, a result of developmental processes of both the mothers and children. However, the young mothers said that the music class was the only time they could get together with their children during the day since the infants usually slept during lunchtime. This meant that during the duration of the program, the young mothers and their children had an opportunity that they would not ordinarily access. Several of the teen mothers did not appear to know how to responsively interact with their children prior to the parent-child music classes. It is unlikely that they would have learned these interactive skills on their own. The parent-child music classes provided specific instructions on bonding (e.g., the importance of eye contact). Further, the music group allowed the mothers to meet and connect in a situation that normalized teen motherhood. The impact of the music curriculum and community bonding that occurred during the classes meant that relationships and resiliency were positively affected. Strengthening resiliency is an important outcome of this study as it reinforces maternal skills and supports infant development.

A further limitation is inherent in the qualitative design and use of participant-observation. There may have been bias toward change. Conversely, other sources of data-focus group interviews, video footage and photographs, individual interviews with the young mothers, and an interview with the music instructor were consistent with the researcher-participant observations.

\subsection{Implications and Conclusion}

This research has implications for those who work with teen mothers and their infants, especially music educators interested in partnering with high school social workers and counselors. Studies of programs situated in schools (e.g., Dunst \& Kassow, 2008) indicate that mutually reinforcing activities involving young mothers and their infants are superior to traditional parenting classes in terms of enhancing mother-child relationships. These mutually reinforcing activities — such as making eye contact, playing and laughing together, and cuddling — are abundant in parent-child music classes. It is thus suggested that parent-child music classes be part of the curriculum for young mothers and their infants.

The teen mothers in the current study were observed to have strengths that were not anticipated given this perspective in the literature. Despite the difficulties they faced, they were resilient, positive, caring parents. The improved dyadic engagement observed in the classes was, to some extent, due to the welcoming, informal, and positive approach taken by the parent-child music instructor when facilitating activities and modeling ways the young mothers could engage with and enjoy their children.

Previous research has found adolescent mothers to be less responsive to their infants than adult mothers (Culp, Appelbaum, Osofsky, \& Levy, 1988) and to know less about play and social development than older mothers (Tamis-Lemonda, Shannon, \& Spellman, 2002). While a few of the young mothers in the current re- 
search appeared to be less responsive during the first classes and know less about child development, the instructor felt that that they only needed a little more time to learn and develop skills and confidence. Parenting expertise develops over time, and helping young mothers to learn skills through finding effective ways to work with them is key. Music is an ideal medium because it is engaging and non-threatening, and reciprocal musical interactions support mother-child attachment and contribute to enhanced socio-emotional, neurological, and developmental outcomes in children (Creighton, 2011).

This study found that teen mothers and their children can benefit from practical interactions that model and reinforce parenting skills through an engaging music program. This research contributes to the existing literature by providing a qualitative understanding of these experiences. The goal in sharing this knowledge, through describing and interpreting the experiences of young mothers and their children in a parent-child music program, is so that others in similar circumstances may benefit.

\section{Funding}

This research was supported by the Social Sciences and Humanities Research Council of Canada.

\section{Note}

This manuscript represents work completed as part of the requirements to complete a Doctor of Philosophy degree at the University of Saskatchewan, Canada. We have no financial interest or benefits arising from the direct application of this research.

\section{References}

Bicknell, J. (2009). Why Music Moves Us. New York, NY: Palgrave Macmillan. http://dx.doi.org/10.1057/9780230233836

Borkowski, J. G., Farris, J. R., Whitman, T. L., Carothers, S. S., Weed, K., \& Keogh, D. A. (2007). Risk and Resilience: Adolescent Mothers and Their Children Grow Up. Mahwah, NJ: Lawrence Erlbaum Associates.

Bowlby, J. (1969). Attachment and Loss (Vol. 1). London, UK: The Hogarth Press.

Braun, V. \& Clarke, V. (2006). Using Thematic Analysis in Psychology. Qualitative Research in Psychology, 3, 77-101. http://dx.doi.org/10.1191/1478088706qp063oa

Burrell, M. (2011). The Benefits of Music Sessions for Very Young Children with Their Parent or Carers Through the Eyes of a Music Therapist. In J. Edwards (Ed.), Music Therapy and Parent-Infant Bonding (pp. 94-100). Oxford, UK: Oxford University Press. http://dx.doi.org/10.1093/acprof:oso/9780199580514.003.0007

Cozolino, L. (2010). The Neuroscience of Psychotherapy. New York, NY: W.W. Norton.

Creighton, A. (2011). Mother-Infant Musical Interaction and Emotional Communication: A Literature Review. The Australian Journal of Music Therapy, 22, 37-56.

Crowe, B. J. (2004). Music and Soul Making: Toward a New Theory of Music Therapy. Toronto, ON: The Scarecrow Press.

Culp, R. E., Appelbaum, M. I., Osofsky, J. D., \& Levy, J. A. (1988). Adolescent and Older Mothers: Comparisons between Prenatal, Maternal Variables, and Newborn Interaction Measures. Infant Behavior and Development, 11, 353-362. http://dx.doi.org/10.1016/0163-6383(88)90019-7

Cunningham, J. (2011). Music Therapy to Promote Attachment between Mother and Baby in Bonding (pp. 115-126). Oxford, UK: Oxford University Press.

Custodero, L. A. (2006). Singing Practices in 10 Families with Young Children. Journal of Research in Music Education, 545, 37-56. http://dx.doi.org/10.1177/002242940605400104

Dissanayake, E. (2000). Antecedents of the Temporal Arts in Early Mother-Infant Interaction. In N. L. Wallin, B. Merker, \& S. Brown (Eds.), The Origins of Music (pp. 389-410). Cambridge, MA: The MIT Press.

Dryfoos, J. G., \& Barkin, C. (2006). Adolescence: Growing up in America Today. Oxford, UK: Oxford University Press. http://dx.doi.org/10.1093/acprof:oso/9780195179613.001.0001

Dunst, C. J., \& Kassow, D. Z. (2008). Caregiver Sensitivity, Contingent Social Responsiveness, and Secure Infant Attachment. Journal of Early and Intensive Behavior Intervention, 5, 40-56. http://dx.doi.org/10.1037/h0100409

Edwards, J. (2011). Music Therapy and Parent-Infant Bonding. Oxford, UK: Oxford University Press. http://dx.doi.org/10.1093/acprof:oso/9780199580514.001.0001

Emery, J., Paquette, D., \& Bigras, M. (2008). Factors Predicting Attachment Patterns in Infants of Adolescent Mothers. Journal of Family Studies, 14, 65-90. http://dx.doi.org/10.5172/jfs.327.14.1.65 
Eshbaugh, E. M., Lempers, J., \& Luze, G. J. (2006). Objective and Self-Perceived Resources as Predictors of Depression among Urban and Non-Urban Adolescent Mothers. Journal of Youth and Adolescence, 35, 833-841. http://dx.doi.org/10.1007/s10964-006-9108-8

Gardner, S. L., \& Goldson, E. (2002). The Neonate and the Environment: Impact on Development. In G. B. Merenstein, \& S. Gardner (Eds.), Handbook of Neonatal Intensive care (5th ed., pp. 219-282). St. Louis, MO: Mosby.

Gay, G. (2002). Preparing for Culturally-Responsive Teaching. Journal of Teacher Education, 53, 106-116. http://dx.doi.org/10.1177/0022487102053002003

Gilligan, C., Spencer, R., Weinberg, M. K., \& Bertsch, T. (2003). On the Listening Guide: A Voice-Centered Relational Method. In P. Camic, J. Rhodes, \& L. Yardley (Eds.), Qualitative Research in Psychology: Expanding Perspectives in Methodology and Design (pp. 157-172). Washington DC: American Psychological Association. http://dx.doi.org/10.1037/10595-009

Gudmundsdottir, H. R., \& Gudmundsdottir, D. G. (2010). Parent-Infant Music Courses in Iceland: Perceived Benefits and Mental Wellbeing of Mothers. Music Education Research, 12, 299-309. http://dx.doi.org/10.1080/14613808.2010.505644

Human Resources and Skills Development Canada (2011). Indicators of Well-Being in Canada. http://www4.hrsdc.gc.ca/h.4m.2@-eng.jsp

Ilari, B. (2005). On Musical Parenting of Young Children: Musical Beliefs and Behaviors of Mothers and Infants. Early Childhood Development and Care, 175, 647-660. http://dx.doi.org/10.1080/0300443042000302573

Kelly, K. (2011). Supporting Attachments in Vulnerable Families through an Early Intervention School-Based Group Music Therapy Programme. In J. Edwards (Ed.), Music Therapy and Parent-Infant Bonding (pp. 101-114). Oxford, UK: Oxford University Press. http://dx.doi.org/10.1093/acprof:oso/9780199580514.003.0008

Kindermusik (2010). About Us. Kindermusik International Inc. www.Kindermusik.com

Ledger, A. (2011). Extending Group Music Therapy to Families in Schools: A Reflection on Practical and Professional Aspects. In J. Edwards (Ed.), Music Therapy and Parent-Infant Bonding (pp. 127-140). Oxford, UK: Oxford University Press. http://dx.doi.org/10.1093/acprof:oso/9780199580514.003.0010

Longhi, E. (2009). "Songese": Maternal Structuring of Musical Interaction with Infants. Psychology of Music, 37, $195-213$. http://dx.doi.org/10.1177/0305735608097042

Luong, M. (2008). Life after Teenage Motherhood. Perspectives on Labour and Income, 9, 5-13. (Statistics Canada Catalogue 75- 001-X) www.statcan.gc.ca/pub/75-001-x/2008105/pdf/10577-eng.pdf

Lyons, S. N. (2000). "Make, Make, Make Some Music": Social Group Work with Mothers and Babies Together. Social Work with Groups, 23, 37-54. http://dx.doi.org/10.1300/J009v23n02 04

MacDonald, M. (2011). Reclaiming Maternal Pedagogies in a British Columbia Aboriginal Head Start program. In D. L. Byrd, \& F. J. Green (Eds.), Maternal Pedagogies in and outside the Classroom (pp. 40-50). Bradford, ON: Demeter Press.

Mackenzie, J., \& Hamlett, K. (2005). The Music Together Program: Addressing the Needs of "Well” Families with Young Children. Australian Journal of Music Therapy, 16, 43-56.

Malloch, S. (1999). Mothers and Infants and Communicative Musicality. Musicae Scientiae, 3, 29-57.

Masten, A. S., Cutuli, J. J., Herbers, J. E., \& Reed, M. J. (2009). Positive Psychology across the Lifespan. In S. J. Lopez, \& C. R. Snyder (Eds.), Oxford Handbook of Positive Psychology (2nd ed., pp. 117-132). Oxford, UK: Oxford University Press.

Nakata, T., \& Trehub, S. E. (2004). Infants' Responsiveness to Maternal Speech and Singing. Infant Behavior and Development, 27, 455-464. http://dx.doi.org/10.1016/j.infbeh.2004.03.002

Newton, R. P. (2008). The Attachment Connection: Parenting a Secure and Confident Child Using the Science of Attachment Theory. Oakland, CA: New Harbinger.

Nicholson, J. M., Berthelsen, D., Abad, V., Williams, K., \& Bradley, J. (2008). Impact of Music Therapy to Promote Positive Parenting and Child Development. Journal of Health Psychology, 13, 226-238. http://dx.doi.org/10.1177/1359105307086705

O'Gorman, S. (2007). Infant-Directed Singing in Neonatal and Paediatric Intensive Care. Australian and New Zealand Journal of Family Therapy, 28, 100-108. http://dx.doi.org/10.1375/anft.28.2.100

Oldfield, A., \& Bunce, L. (2001). "Mummy Can Play Too..." Short-Term Music Therapy with Mothers and Young Children. British Journal of Music Therapy, 15, 27-36. http://dx.doi.org/10.1177/135945750101500107

Oldfield, A., Adams, M., \& Bunce, L. (2003). An Investigation into Short-Term Music Therapy with Mothers and Young Children. British Journal of Music Therapy, 17, 26-45. http://dx.doi.org/10.1177/135945750301700105

Olsen, S. (2005). Just Ask Us: A Conversation with First Nations Teenage Moms. Winlaw, BC: Sono Nis Press.

Olsson, C. A., Bond, L., Burns, J. M., Vella-Brodrick, D. A., \& Sawyer, S. M. (2003). Adolescent Resilience: A Concept 
Analysis. Journal of Adolescence, 26, 1-11. http://dx.doi.org/10.1016/S0140-1971(02)00118-5

Papousek, M. (1996). Intuitive Parenting: A Hidden Source of Musical Stimulation in Infancy. In I. Deliage, \& J. Sloboda (Eds.), Musical Beginnings: Origins and Development of Musical Competence (pp. 88-12). New York: Oxford University Press. http://dx.doi.org/10.1093/acprof:oso/9780198523321.003.0004

Raikes, H. A., \& Thompson, R. A. (2008). Attachment Security and Parenting Quality Predict Children's Problem-Solving, Attributions, and Loneliness with Peers. Attachment and Human Development, 10, 319-344. http://dx.doi.org/10.1080/14616730802113620

Rolfe, S. (2004). Rethinking Attachment for Early Childhood Practice: Promoting Security, Autonomy and Resilience in Young Children. New South Wales: Allen \& Unwin.

Sadler, L. S., Swartz, M. K., \& Ryan-Krause, P. (2003). Supporting Adolescent Mothers and Their Children through a High School Based Child Care Center and Parent Support Program. Journal of Pediatric Health Care, 17, 109-117.

Schneck, D. J., Berger, D. S., \& Rowland, G. (2006). The Music Effect: Music Physiology and Clinical Applications. Philadelphia, PA: Jessica Kingsley Publishers.

Schore, A. N. (2001). Effects of a Secure Attachment Relationship on Right Brain Development, Affect Regulation and Infant Mental Health. Infant Mental Health Journal, 22, 7-66.

http://dx.doi.org/10.1002/1097-0355(200101/04)22:1<7::AID-IMHJ2>3.0.CO;2-N

Seligman, M. E. (2011). Flourish: A Visionary New Understanding of Happiness and Wellbeing. New York: Free Press/Simon \& Schuster.

Shenfield, T., Trehub, S. E., \& Nakata, T. (2003). Maternal Singing Modulates Infant Arousal. Psychology of Music, 31, 365-375. http://dx.doi.org/10.1177/03057356030314002

Siegel, D. J. (1999). The Developing Mind: How Relationships and the Brain Interact to Shape Who We Are. New York: The Guildford Press.

Stake, R. E. (2010). Qualitative Research: Studying How Things Work. New York: Guilford Press.

Steele, H., Steele, M., \& Croft, C. (2008). Early Attachment Predicts Emotion Recognition at 6 and 11 Years Old. Attachment and Human Development, 10, 379-393. http://dx.doi.org/10.1080/14616730802461409

Tafuri, J. (2008). Infant Musicality: New Research for Educators and Parents. Surrey: Ashgate.

Tamis-Lemonda, C. S., Shannon, J., \& Spellman, M. (2002). Low-Income Adolescent Mothers' Knowledge about Domains of Child Development. Infant Mental Health Journal, 23, 88-103. http://dx.doi.org/10.1002/imhj.10006

Tarabulsy, G. M., Moran, G., Pederson, D. R., Provost, M., \& Larose, S. (2011). Adolescent Motherhood, Maternal Sensitivity, and Early Infant Development. In D. W. Davis, \& M. C. Logsdon (Eds.), Maternal Sensitivity: A Scientific Foundation for Practice (pp. 157-178). New York: Nova Science.

Taylor, J. (1806). Twinkle, Twinkle, Little Star. London: Harvey \& Darton.

Thompson, R. A. (2008). Early Attachment and Later Development. In J. Cassidy, \& P. R. Shaver (Eds.), Handbook of Attachment (2nd ed., pp. 348-365). New York: The Guildford Press.

Trainor, L. J. (1996). Infant Preferences for Infant-Directed versus Noninfant-Directed Playsongs and Lullabies. Infant Behavior and Development, 19, 89-92. http://dx.doi.org/10.1016/S0163-6383(96)90046-6

Van Ijzendoorn, M. H., Schuengel, C., \& Bakermans-Kranenburg, M. J. (1999). Disorganized Attachment in Early Childhood: Meta-Analysis of Precursors, Concomitants, and Sequelae. Development and Psychopathology, 11, 224-249. http://dx.doi.org/10.1017/s0954579499002035

Weinfield, N. S., Sroufe, L. A., Egeland, B., \& Carlson, E. (2008). Individual Differences in Infant-Caregiver Attachment. In J. Cassidy, \& P. R. Shaver (Eds.), Handbook of Attachment (2nd ed., pp. 78-101). New York: The Guildford Press. 